\title{
15. LOW-TEMPERATURE ALTERATION OF PERIDOTITE, HOLE 637A ${ }^{1}$
}

\author{
Cynthia A. Evans, ${ }^{2}$ Lamont-Doherty Geological Observatory, Palisades, New York \\ and \\ Miriam Baltuck, EEL, NASA, Washington, D.C.
}

\section{INTRODUCTION}

The peridotite recovered from Ocean Drilling Program Hole 637A, Galicia margin, has suffered extensive low-temperature alteration that includes serpentinization, calcite veining, and calcite replacement. This note presents textural and geochemical data on the serpentine and calcite. Such data indicate that the serpentinization, serpentine veining, and calcite veining of the peridotite occurred in several stages late in the history of the peridotite emplacement, probably after the peridotite was emplaced at crustal levels. It is also apparent that some deformational events (evidenced by faulting and brecciation of both serpentine and calcite veins) continued after the main phase of low-temperature alteration. The geochemistry and petrology, structure, and high-temperature alteration of the peridotite are discussed in separate papers in this volume (Evans and Girardeau; Girardeau et al.; Kimball and Evans; Agrinier et al.).

\section{LITHOLOGIC DESCRIPTIONS}

Most of the peridotite recovered is a clinopyroxene-rich harzburgite that is highly altered to secondary minerals (see "Site 637" chapter for further descriptions; Shipboard Scientific Party, 1987). Serpentine is the predominant mineral and replaces both olivine and orthopyroxene. Parts of the core are also extensively replaced by calcite. Near the top of the peridotite (Cores 103637A-23R and 103-637A-24R), microveins of calcite comprise over $50 \%$ of the rock, and calcite rims and replaces pyroxene (see Evans and Girardeau, this volume) and serpentine. The middle part of the recovered peridotite has less matrix-replacing calcite but contains radial aggregates of calcite and small- and large-zoned (Fig. 1) and vugged calcite veins. The large calcite veins often contain euhedral magnetite and other oxides (Fig. 2 ). The serpentine and calcite veins crosscut the original foliation of the rock, as well as the earlier formed mesh serpentine. Several generations of veining have occurred, as evidenced by crosscutting and/or zoned veins (Fig. 1).

Given the textural relationships observed in the core, the lowtemperature alteration sequence is as follows:

1. Formation of mesh serpentine.

2. Formation of serpentine veins: early veins appear to parallel foliation, later veins tend to cut the foliation at a high angle.

3. Calcite replacement and calcite veining (Fig. 1).

4. Brecciation and deformation of the peridotite to form serpentine and calcite breccias (Fig. 3).

\footnotetext{
${ }^{1}$ Boillot, G., Winterer, E. L., et al., 1988. Proc. ODP, Sci. Results, 103: College Station, TX (Ocean Drilling Program).

2 Present Address: CA8, NASA, Johnson Space Center, Houston, TX 77058.
}

Geochemical and petrographic data on serpentine and calcite will be discussed separately in the following sections.

\section{ANALYTICAL METHODS}

All samples were petrographically studied by thin section in order to determine extent, habit, and structural relations of the late-stage alteration minerals. Over 50 samples of serpentine veins, calcite veins, and whole-rock serpentinites (with matrix calcite) were examined for polymorph and compositional types with X-ray diffraction (XRD), using the facilities at Colgate University. Whole-rock samples were simply ground to a powder. Veins were separated and picked clean by hand before powdering. Microprobe analyses of a handful of calcite and serpentine samples were obtained to verify the data collected both optically and by XRD.

In order to identify the origin and conditions of precipitation of the calcite, nine samples from the peridotite at the base of Hole 637A were chosen for carbon- and oxygen-isotope analysis. These samples included seven samples of matrix calcite (replacing mesh serpentine) and two samples of vein calcite. Samples of matrix-replacing calcite were powdered and measured without attempt to isolate the calcite phase. Vein calcite was selected from vein-bearing serpentinite samples that were broken into small pieces from which calcite was handpicked and powdered for isotope analysis.

Isotope analysis was performed on the VG Micromass 602 mass spectrometer at Scripps Institution of Oceanography. Samples were dissolved in phosphatic acid at $50^{\circ} \mathrm{C}$. Isotopic composition is reported in parts per mil (\%) deviation from Peedee belemnite (PDB) standard using the notation

$$
\begin{aligned}
\delta^{13} \mathrm{C} & =\left[\left({ }^{13} \mathrm{C} /{ }^{12} \mathrm{C}_{\text {sample }}-{ }^{13} \mathrm{C} /{ }^{12} \mathrm{C}_{\text {standard }}\right) /\left({ }^{13} \mathrm{C} /{ }^{12} \mathrm{C}_{\text {standard }}\right)\right] \times 1000 \\
\delta^{18} \mathrm{O} & =\left[\left({ }^{18} \mathrm{O} /{ }^{16} \mathrm{O}_{\text {sample }}-{ }^{18} \mathrm{O} /{ }^{16} \mathrm{O}_{\text {standard }}\right) /\left({ }^{18} \mathrm{O} /{ }^{16} \mathrm{O}_{\text {standard }}\right)\right] \times 1000 .
\end{aligned}
$$

The results for oxygen isotopes in the calcite are then converted to \%o deviation standard mean ocean water (SMOW) so that they can be compared with the serpentine oxygen-isotope values. The equation for the conversion used (Faure, 1977) is

$$
\delta^{18} \mathrm{O}_{\text {SMOW }}=1.030378\left(\delta^{18} \mathrm{O}_{\text {sample }}-\mathrm{PDB}\right)+30.37 .
$$

Oxygen isotopes were measured on 10 serpentine samples. In order to choose samples without calcite, these samples were selected after petrographic and XRD analyses. The samples were crushed to sand-sized particles, and pretreated with $\mathrm{BrF}_{5}$ to strip any adsorbed water from the samples. The samples were then analyzed using the facilities at IGPP, University of California, Riverside. The values for oxygen are reported relative to SMOW and were checked by reference to NBS-28 and two other silicate standards.

\section{GEOCHEMICAL DATA}

\section{Calcite}

All of the carbonate material is calcite; no aragonite was observed. The calcite has very uniform compositions with low $\mathrm{Mg}$ concentrations (Table 1). XRD and microprobe data suggest only minor compositional differences in all of the samples analyzed, including zoned veins, matrix calcite, and calcite rims on 


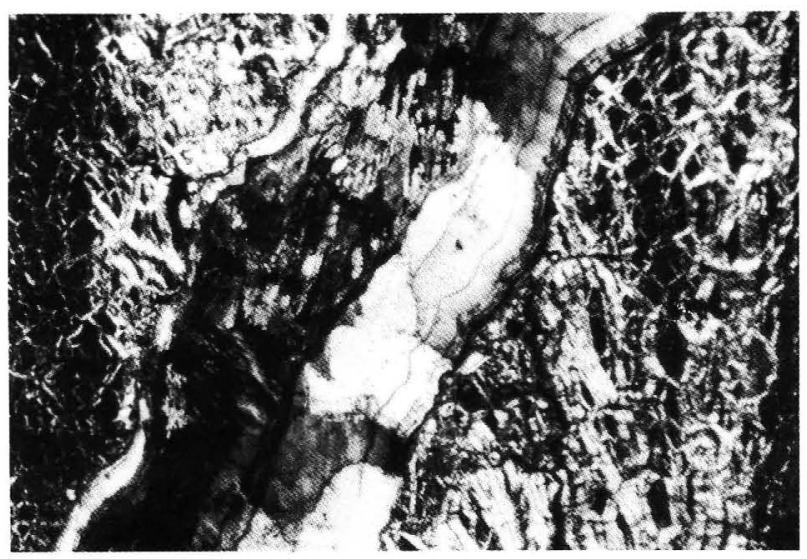

A

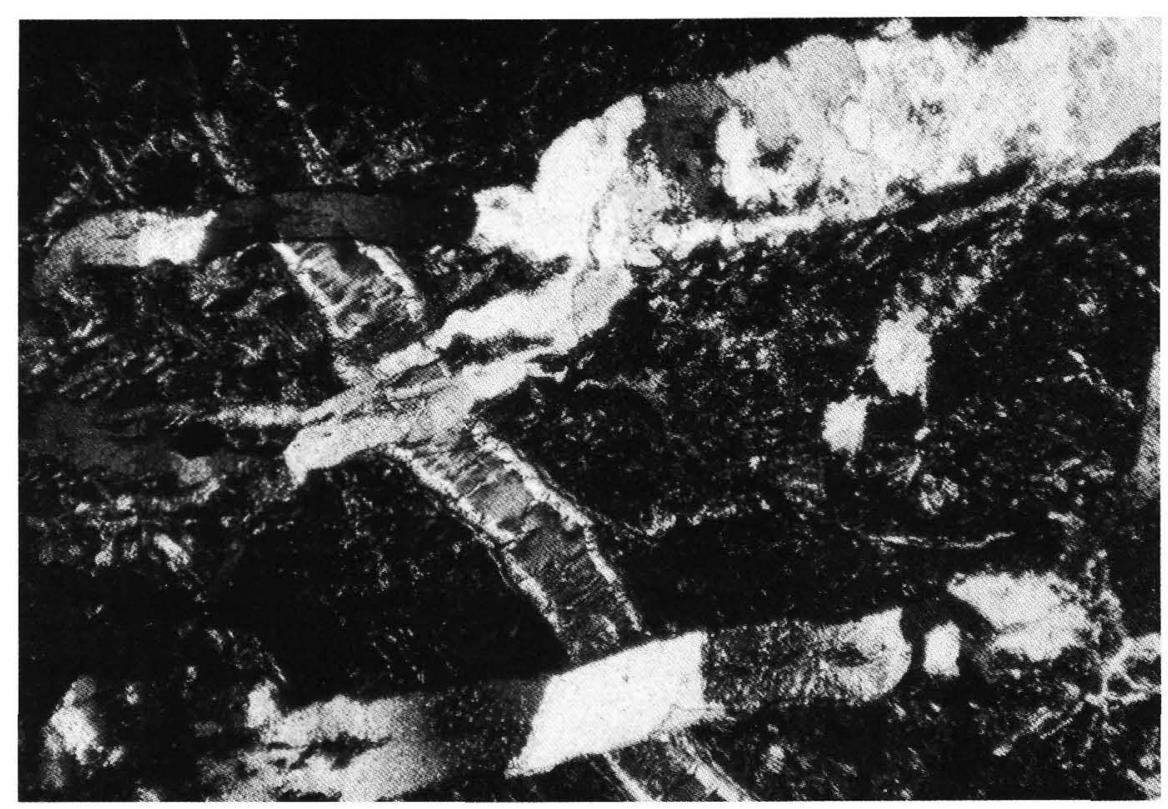

B

Figure 1. Photomicrographs of calcite and serpentine veins in peridotite (103-637A-25R-5, 199-121 $\mathrm{cm}$ ). Scale bars are $1 \mathrm{~mm}$. A. Zoned calcite (right side) and serpentine (left side) vein cutting through serpentine mesh. B. Calcite veins crosscutting serpentine vein that cuts serpentine meshwork.

pyroxenes. The stable-isotope data from the calcite samples are also quite uniform; $\delta^{18} \mathrm{O}$ values range from $0.1 \%$ to $0.63 \% 0$ PDB; $\delta^{13} \mathrm{C}$ varies from $-0.87 \%$ to $1.82 \%$ PDB (Table 2).

\section{Serpentine}

The most predominant serpentine polymorph is chrysotile (especially in veins), but mixtures of chrysotile and lizardite are also common. No antigorite has been observed, even along shear zones. The observed habits and polymorphs of serpentine are very similar to those described by Prichard (1979). Systematic differences in serpentine compositions were not observed between the different types of serpentine occurrences (e.g., veins parallel to or at a high angle to the foliation, matrix serpentine, serpentine breccia).

Iron oxides have also formed during serpentine and calcite formation. The habits of the oxide minerals include large euhedral grains within calcite veins (with $>1 \% \mathrm{MnO}$ and $0.48 \% \mathrm{Cr}_{2} \mathrm{O}_{3}$;
Fig. 3), rims on chromium spinel grains, and small dusty-looking opaques disseminated throughout the rock.

Oxygen isotope data from serpentine samples display a large range of values $\left(\delta^{18} \mathrm{O}=6.5 \% 0^{-14.8 \% 0} \mathrm{SMOW}\right)$, but this is within the range of values observed for other serpentinites (Wenner and Taylor, 1971, 1973; Bonatti et al., 1980).

\section{DISCUSSION}

The isotope results from the calcite are illustrated in Figure 4. All $\delta^{18} \mathrm{O}$ values are $0.75 \% 0-0.00 \%$ (PDB), indicating that the calcite precipitated in seawater at typical deep-sea temperatures (Craig and Gordon, 1965). The $\delta^{18} \mathrm{O}$ values of the calcite vein samples are within the same range as for the matrix samples. These data indicate that the calcite was not formed at elevated temperatures, either during deep burial or when the peridotite was at higher temperatures at depth. 


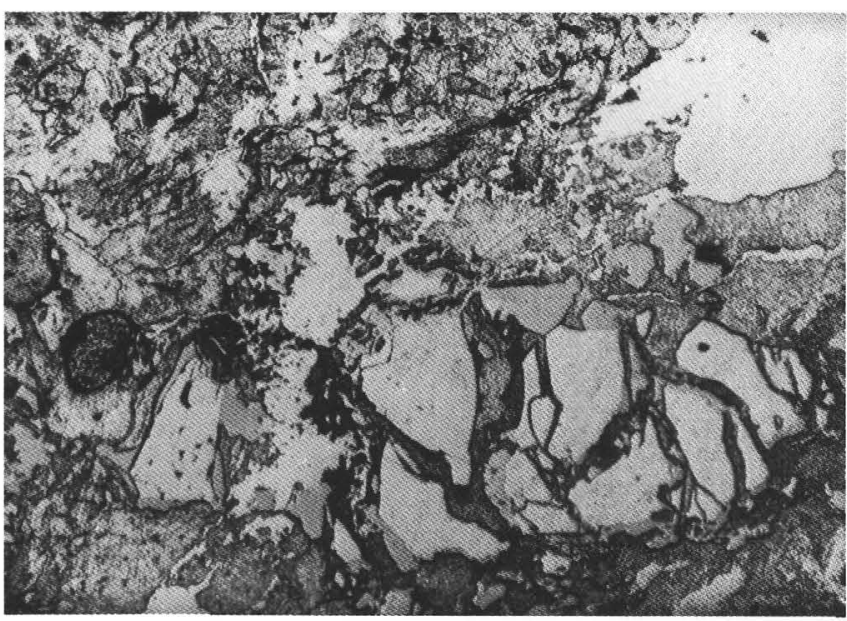

A

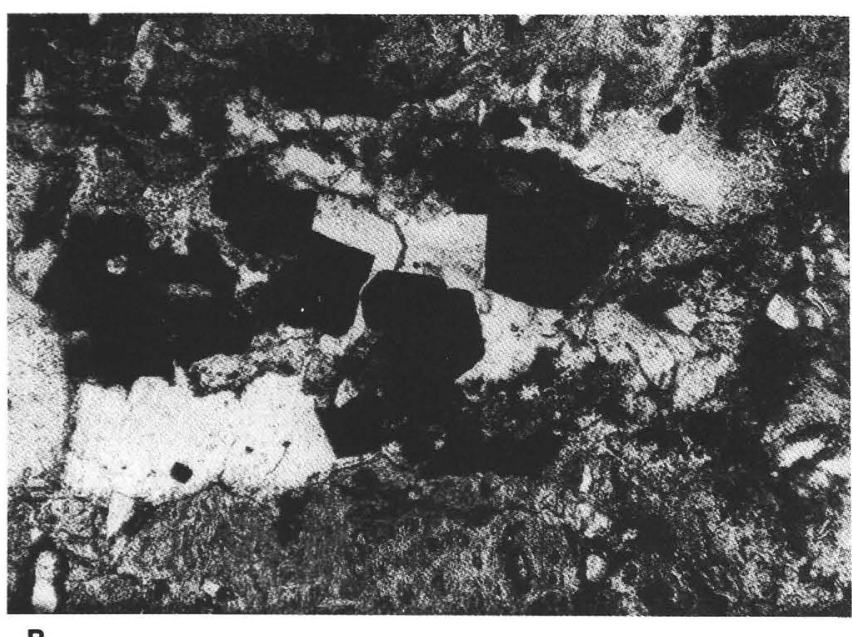

B

Figure 2. Photomicrographs of oxides in peridotite (Sample 103-637A25R-1, 31-33 cm). Scale bars are $1 \mathrm{~mm}$. A. Reflected-light photomicrograph of chromite grain (light colored) with rims of magnetite (darker). B. Magnetite grains inside calcite vein.

Carbon isotope data from the calcite samples indicate slight differences in $\delta^{13} \mathrm{C}$ values between matrix and vein calcite samples. All values are within $1.82 \% 0$ of seawater ( $0 \% 0 \mathrm{PDB})$, but matrix calcite $(0.40 \% 0-1.82 \% 0)$ is slightly heavier than vein calcite $(-0.44 \%$ to $-0.87 \%$ ) .

The ${ }^{13} \mathrm{C}$ values are relatively insensitive to changes in temperatures of precipitation (Emrich et al., 1970). A possible explanation for the difference in carbon isotope values between the matrix and vein calcite is that the dissolution of the matrix calcite resulted in pore waters enriched slightly in lighter carbon, which was incorporated in subsequent precipitation of vein calcite.

The range in $\delta^{18} \mathrm{O}$ in serpentine is large, from $6.5 \% 0_{0}-14.8 \% 0$ (SMOW). This range could be due to any of the following:

1. Calcite in the sample. Small amounts of calcite could go undetected by XRD. Given the high $\delta^{18} \mathrm{O}$ of calcite, a small amount of contaminant could raise the whole-rock value.

2. Magnetite in the sample. Oxides are ubiquitous in these serpentinized samples, and their presence (in variable amounts) could lower the $\delta^{18} \mathrm{O}$ values.

3. Variable fluid/rock ratios. High fluid/rock would yield high $\delta^{18} \mathrm{O}$ values.
Table 1. Microprobe analyses of calcite.

\begin{tabular}{lcc}
\hline & $\begin{array}{c}\text { 103-637A-28R-1, } \\
81-83 \mathrm{~cm} \\
\text { (rim on clinopyroxene) }\end{array}$ & $\begin{array}{c}\text { 103-637A-25R-1, } \\
31-33 \mathrm{~cm} \\
\text { (vein in orthopyroxene) }\end{array}$ \\
\hline $\mathrm{CaO}$ & 57.97 & 59.67 \\
$\mathrm{MgO}$ & 1.68 & 1.12 \\
$\mathrm{FeO}$ & 0.11 & 0.13 \\
Total & $\underline{59.84}$ & 61.03 \\
\hline
\end{tabular}

Table 2. Stable isotope data for serpentine and calcite.

\begin{tabular}{|c|c|c|c|c|c|}
\hline \multirow[b]{2}{*}{ Sample } & \multicolumn{3}{|c|}{ Calcite } & \multicolumn{2}{|c|}{ Serpentine } \\
\hline & $\begin{array}{c}\delta^{18} \mathrm{O} \\
\mathrm{PDB} \\
(\% 0)\end{array}$ & $\begin{array}{c}\delta^{13} \mathrm{C} \\
\mathrm{PDB} \\
(\%)\end{array}$ & $\begin{array}{c}\delta^{18} \mathrm{O} \\
\text { SMOW } \\
(\% 0)\end{array}$ & $\begin{array}{c}\delta^{18} \mathrm{O} \\
\text { SMOW } \\
(\% 0)\end{array}$ & Type \\
\hline $\begin{array}{l}\text { 103-637A-26R-3, } 63 \mathrm{~cm} \\
\text { 26R-3, } 72 \mathrm{~cm} \\
\text { 25R-3, } 62 \mathrm{~cm} \\
24 \mathrm{R}-1,56 \mathrm{~cm} \\
25 \mathrm{R}-1,116 \mathrm{~cm} \\
26 \mathrm{R}-1,0-4 \mathrm{~cm} \\
28 \mathrm{R}-2,58-62 \mathrm{~cm} \\
24 \mathrm{R}-2,82 \mathrm{~cm} \\
27 \mathrm{R}-1,123 \mathrm{~cm} \\
27 \mathrm{R}-2,65-68 \mathrm{~cm} \\
25 \mathrm{R}-4,41-44 \mathrm{~cm} \\
27 \mathrm{R}-1,138-140 \mathrm{~cm} \\
28 \mathrm{R}-1,36-39 \mathrm{~cm} \\
29 \mathrm{R}-1,80-82 \mathrm{~cm} \\
26 \mathrm{R}-1,33-35 \mathrm{~cm} \\
26 \mathrm{P}-100 \mathrm{~cm}\end{array}$ & $\begin{array}{l}0.27 \\
0.13 \\
0.12 \\
0.48 \\
0.09 \\
0.27 \\
0.6 \\
0.52 \\
0.63\end{array}$ & $\begin{array}{r}-0.87 \\
-0.59 \\
-0.44 \\
0.40 \\
0.95 \\
1.39 \\
1.44 \\
1.68 \\
1.82\end{array}$ & $\begin{array}{l}30.65 \\
30.50 \\
30.49 \\
30.86 \\
30.46 \\
30.65 \\
30.99 \\
30.90 \\
31.02\end{array}$ & $\begin{array}{r}10.0 \\
10.2 \\
13.7 \\
10.4 \\
9.0 \\
14.8 \\
12.0 \\
12.9\end{array}$ & $\begin{array}{l}\text { Vein } \\
\text { Vein } \\
\text { Vein } \\
\text { Matrix } \\
\text { Matrix } \\
\text { Matrix } \\
\text { Matrix } \\
\text { Matrix } \\
\text { Matrix } \\
\text { Rock } \\
\text { Rock } \\
\text { Vein } \\
\text { Rock } \\
\text { Rock } \\
\text { Vein } \\
\text { Rock } \\
\text { Rock }\end{array}$ \\
\hline
\end{tabular}

4. The waters responsible for serpentinization had previously exchanged with overlying carbonate material and became enriched in ${ }^{18} \mathrm{O}$ (e.g., Clayton et al, 1966).

5. Variable temperatures of serpentinization, which document different stages of serpentinization during the ascent of the peridotite (e.g., Bonatti et al., 1984).

6. Fluids responsible for serpentinization became enriched in ${ }^{18} \mathrm{O}$ from other high-temperature reactions at deeper levels in the intrusion.

Although no antigorite (high-temperature) serpentine was found, it is possible that the range of oxygen isotope values in the serpentine record different temperatures of serpentinization. Amphibole veining and replacement of pyroxene are evidence for earlier hydrothermal events at much higher temperatures $\left(350^{\circ}-900^{\circ} \mathrm{C}\right.$; Kimball and Evans, this volume). The stable-isotope data collected do not allow significant trends to be identified in $\delta^{18} \mathrm{O}$ values for different serpentine generations (i.e., different types of veins and matrix serpentine). However, water/ rock ratios may have been quite high in samples with high $\delta^{18} \mathrm{O}$ values. These samples are the most altered samples, which occur at the top of the peridotite and in the fractured peridotite at the bottom of the hole.

The calcite veins have, for the most part, formed after serpentinization, and stable-isotope data suggest that the calcite formed from seawater at deep-sea temperatures. Other such occurrences of carbonate material in abyssal serpentinites (dredge samples of ultramafic-carbonate breccias from the Romanche and Vema Fracture Zones; Bonatti et al., 1974, 1980) give similar isotopic values. However, these breccias contain aragonite in addition to zoned carbonate veins and calcite replacing serpentine.

It has been observed that the interstitial waters in veins and fractures in serpentinized peridotite have a high $\mathrm{pH}$ and concen- 


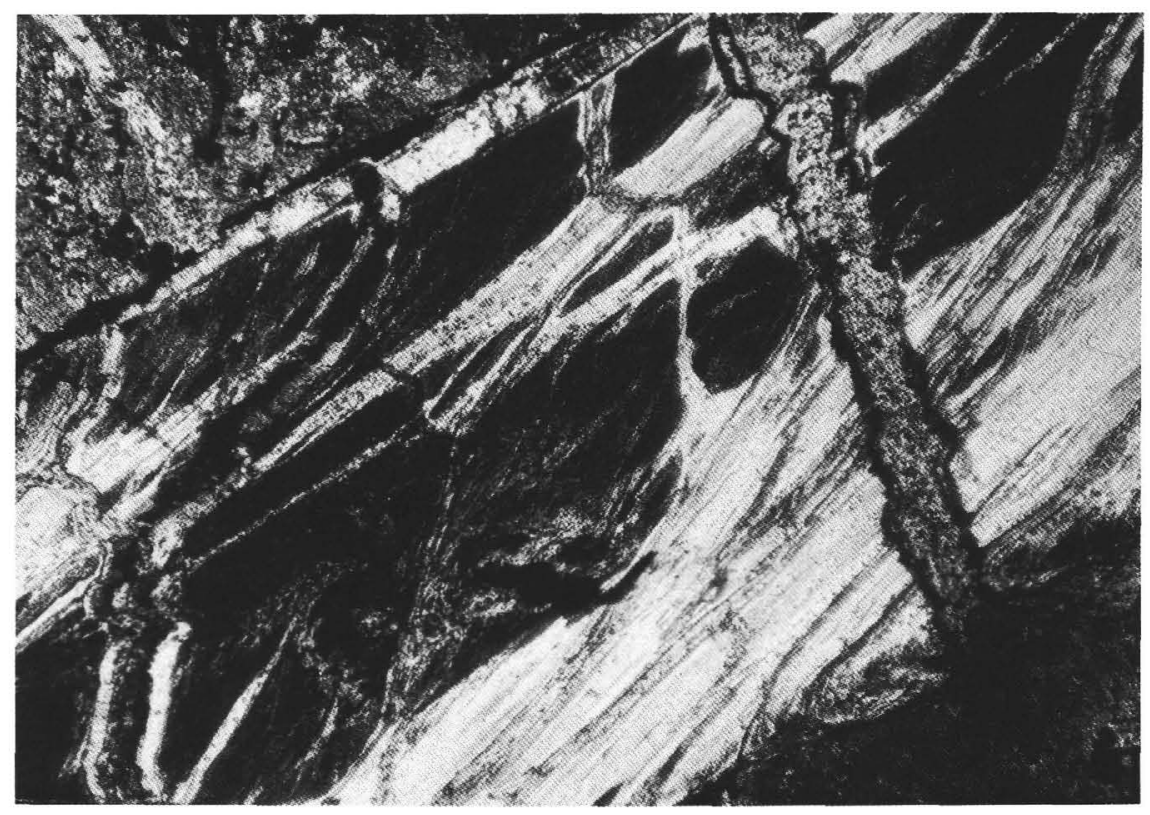

A

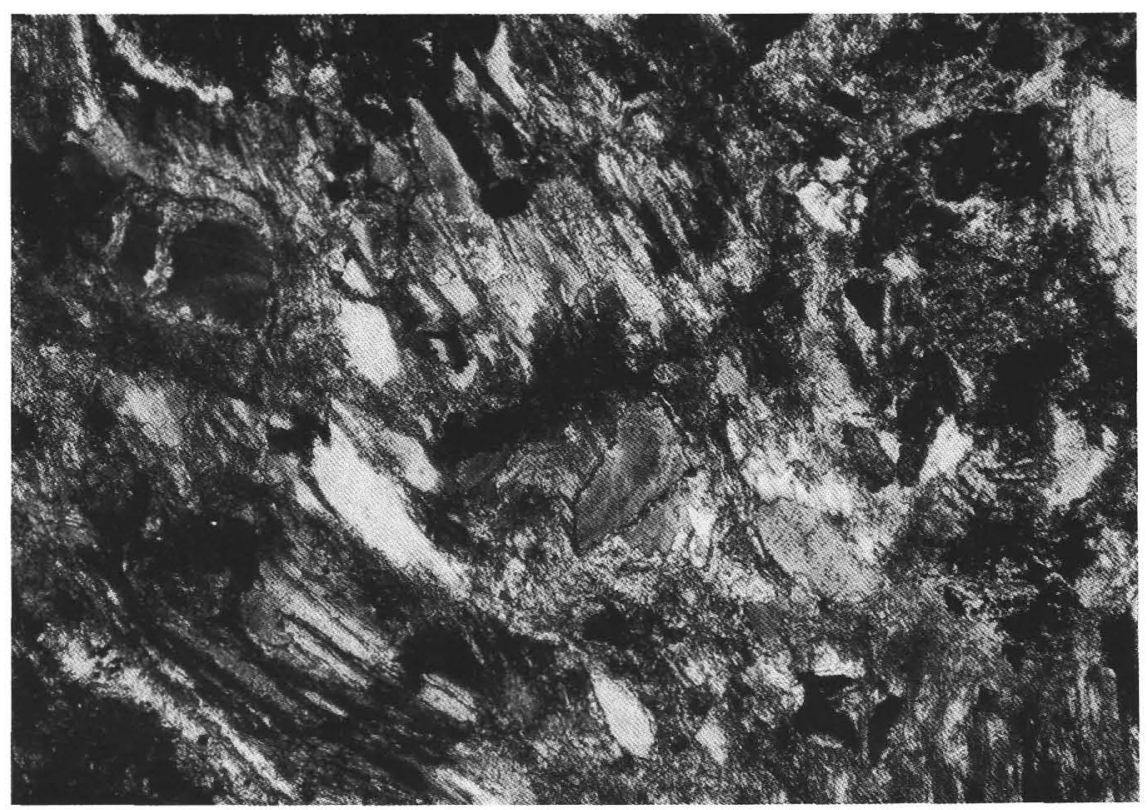

B

Figure 3. Photomicrographs of serpentine-calcite breccia, Sample 103-637A-28R-3, 69-72 cm. Scale bar is $1 \mathrm{~mm}$. A. Large vein of serpentine rimmed with calcite (top) and cut by a later serpentine vein. B. Serpentine calcite breccia. Pieces of serpentine and calcite in a fine-grain matrix of serpentine and calcite.

tration of dissolved $\mathrm{Mg}$ (Janecky and Seyfried, 1986). The high $\mathrm{pH}$ favors a supersaturation with respect to $\mathrm{CaCO}_{3}$ (Bonatti et al., 1974, 1980) so that the calcite and aragonite can precipitate. Although no aragonite has been found in the Hole 637A samples, it could have been recrystallized to calcite. The calcite in the abyssal samples is also $\mathrm{Mg}$ rich, with $4 \%-16 \% \mathrm{MgO}$ (Bonatti et al., 1974, 1980).

The style and amount of calcite in the rock can be used to map out seawater circulation patterns and extents of seawater circulation in the peridotite. The upper part of the peridotite (Cores 103-637A-23R and 103-637A-24R) has a leached appearance and is extensively replaced by calcite. It is suggested that the upper peridotite was highly fractured, which allowed extensive seawater circulation along microcracks and grain boundaries. Further downcore, the rock is less fractured and is relatively fresh, with much less calcite replacement. Instead, large veins of calcite occur, indicating that seawater was preferentially channeled through large fractures and did not percolate through 


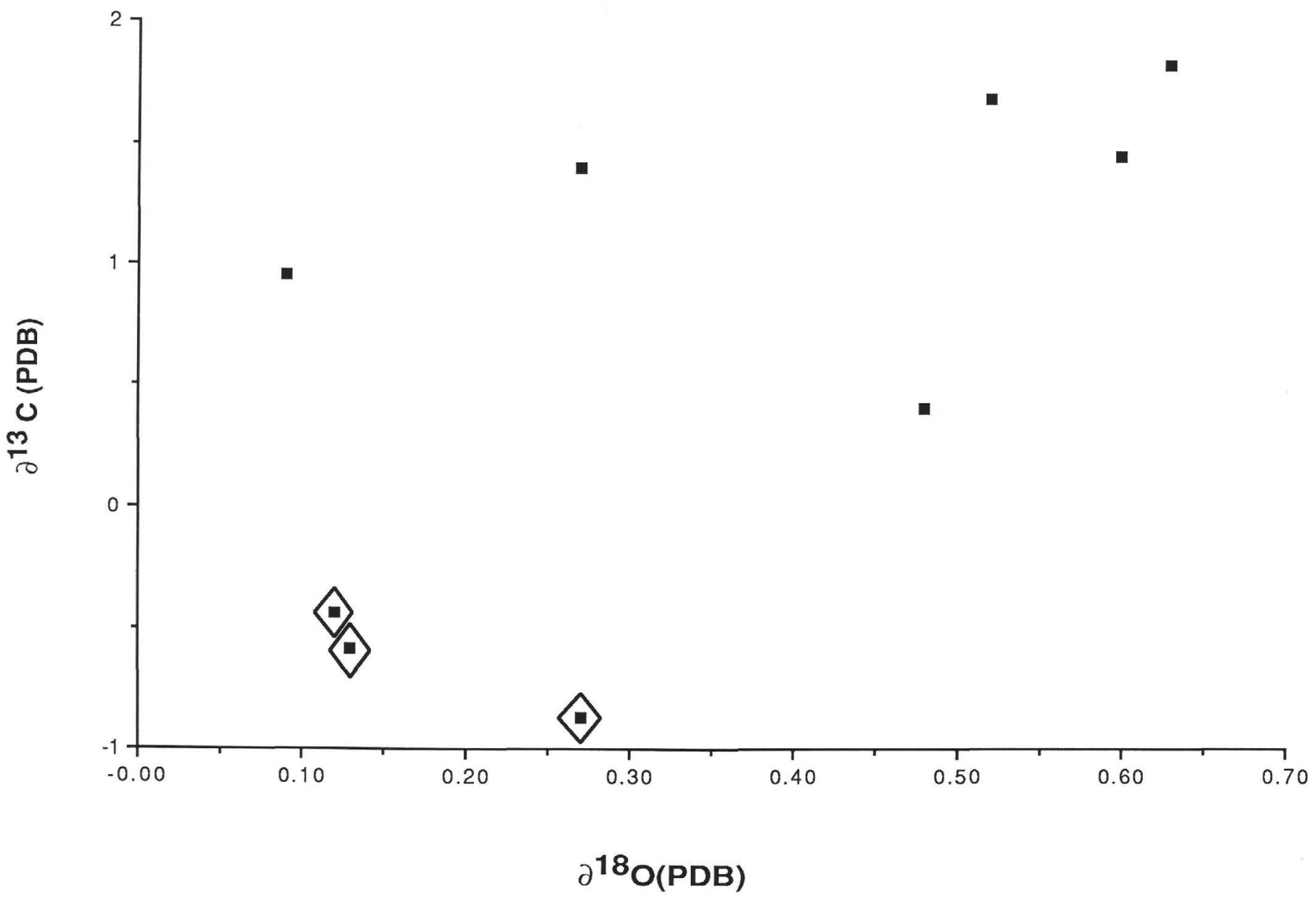

Figure 4. Stable isotopes for calcite samples. Vein samples in diamonds; plain squares are matrix samples.

the rock along small fractures and grain boundaries. At the bottom of the core, the rock is again highly fractured and brecciated and is also heavily altered with matrix calcite. Large volumes of water must have circulated through this faulted region.

\section{SUMMARY}

In summary, the peridotite recovered at Hole $637 \mathrm{~A}$ has suffered extensive low-temperature and late-stage alteration, which includes serpentinization, serpentine and calcite veining, and replacement by calcite. The more fractured and faulted regions of the cores are the most altered. In less fractured rock, fluids appear to have been channeled through established fractures, now evident as large calcite veins.

Stable-isotope data indicate that the fluid responsible for serpentinization was probably seawater, and that water/rock ratios may have been high. The calcite was precipitated from seawater at deep-sea temperatures and thus, was precipitated after the peridotite was emplaced at or near the seafloor surface.

\section{ACKNOWLEDGMENTS}

We gratefully acknowledge S. Rasbury for sample preparation of the calcite samples and A. Williams for the serpentine isotope analyses. This manuscript was reviewed by D. Stakes and E. Bonatti.

\section{REFERENCES}

Bonatti, E., Emiliani, C., Ferrar, G., Honnorez, J., and Rydell, H., 1974. Ultramafic-carbonate breccias from the equatorial Mid-Atlantic Ridge. Mar. Geol., 16:83-102.

Bonatti, E., Lawrence, J. R., Hamlyn, P. R., and Breger, D., 1980. Aragonite from deep sea ultramafic rocks. Geochim. Cosmochim. Acta, 44:1207-1214.
Bonatti, E., Lawrence, J. R., and Morandi, N., 1984. Serpentinization of oceanic peridotites: temperature dependence of mineralogy and boron content. Earth Planet. Sci. Lett., 70:88-94.

Clayton, R. N., Friedman, I., Graf, D., Mayeda, T. K., Meents, W. F., and Shimp, N. F., 1966. The origin of saline formation waters. I. Isotopic composition. J. Geophys. Res., 71:3869-3882.

Craig, H., and Gordon, L. I., 1965. Isotopic oceanography: deuterium and oxygen 18 variations in the ocean and the marine atmosphere. Mar. Geochem., Proc. Symp., 1964, 277-374.

Emrich, K., Ekhalt, D. H., and Vogel, J. C., 1970. Carbon isotope fractionation during the precipitation of calcium carbonate. Earth Planet. Sci. Lett., 8:363-371.

Faure, G., 1977. Principles of Isotope Geology: New York (Wiley).

Janecky, D. R., and Seyfried, W. E., Jr., 1986. Hydrothermal serpentinization of peridotite within the oceanic crust: experimental investigations of mineralogy and major element chemistry. Geochim. Cosmochim. Acta, 50:1357-1378.

Prichard, H., 1979. A petrographic study of serpentinization in ophiolites and the ocean crust. Contrib. Mineral. Petrol., 68:231-241.

Shipboard Scientific Party, 1987. Site 637. In Boillot, G., Winterer, E. L., et al., Proc. ODP, Init. Repts., 103: College Station, TX (Ocean Drilling Program, 123-219.

Wenner, D. B., and Taylor, H. P., Jr., 1971. Temperatures of serpentinization of ultramafic rocks based on ${ }^{18} \mathrm{O} /{ }^{16} \mathrm{O}$ fractionation between coexisting serpentine and magnetite. Contrib. Mineral. Petrol., 32: 165-185.

1973. Oxygen and hydrogen isotope studies of the serpentinization of ultramafic rocks in oceanic environments and continental ophiolite complexes. Am. J. Sci., 273:207-239.

Date of initial receipt: 21 January 1987

Date of acceptance: 30 June 1987

Ms 103B-139 